\title{
MEKANISME PEMBERIAN BANTUAN KEPADA MASYARAKAT NELAYAN DI DESA LABUHAN BHAKTI, KABUPATEN SIMEULUE PROPINSI NANGGROE ACEH DARRUSSALAM
}

\author{
Oleh: \\ Rizky Muhartono dan Zahri Nasution *
}

\begin{abstract}
ABSTRAK
Secara khusus tsunami berdampak besar terhadap kehidupan nelayan. Tulisan ini bertujuan mengkaji mekanisme pemberian bantuan terhadap masyarakat nelayan setelah terjadinya gempa dan tsunami di Desa Labuhan Bhakti Kabupaten Simeulue, Propinsi Nangroe Aceh Darussalam (NAD). Riset dilakukan menggunakan pendekatan studi kasus pada mekanisme pemberian bantuan kepada masyarakat nelayan. Data yang digunakan adalah data primer dan data sekunder. Pengumpulan data dilakukan menggunakan pendekatan survei terhadap responden menggunakan cara wawancara semi terstruktur dengan panduan beberapa topik data. Data yang diperoleh baik data primer maupun data sekunder dianalisis secara deskriptif. Hasil riset menunjukkan bahwa gempa bumi dan tsunami yang terjadi di Kabupaten Simeulue telah mengakibatkan rusaknya sarana dan fasilitas di sektor kelautan dan perikanan, bahkan korban jiwa pada masyarakat nelayan. Pemberian bantuan kepada masyarakat nelayan di Kabupaten Simeulue melalui beberapa tahapan, mulai dari menentukan lokasi penerima bantuan dan kelompok pendamping, hingga pentahapan yang berupa kegiatan pendaftaran, pendaftaran ulang, penegasan, penguatan organisasi dan administrasi. Kemudian, dilanjutkan dengan penguatan modal, usaha produktif dan penguatan jaringan menuju tahap pengembangan usaha. Program pendampingan telah berhasil dilakukan pada nelayan setempat yang ditunjukkan oleh dua aspek yaitu respon masyarakat dan aspek ekonomi. Disarankan proses pemberian bantuan terhadap nelayan memperhatikan kondisi sosial budaya, adat dan kebiasaan dalam menangkap ikan, sehingga bantuan dapat berguna bagi nelayan, melalui proses need assessment yang dilakukan secara cepat, tepat dan terarah.
\end{abstract}

Kata kunci : Mekanisme dan Pemberian Bantuan, Nelayan, Labuhan Bhakti,

\section{Abstract : The Giving Aid Mechanism to the Fishers at Labuhan Bhakti Village, Simeulue District, Nanggroe Aceh Darrussalam Province. By: Rizky Muhartono and Zahri Nasution}

Specially, tsunami has big impact for fishers. The aim of this paper is to recite the aid mechanism for fishers after tsunami and earthquake at Labuhan Bhakti Village, Simeulue District Nanggroe Aceh Darrussalam Province. This reaserch was done by using case study approach in term to see fishers aid mechanism. Primary and secondary data was used. Data was collected by using survey approach to responden that contain semi-structure interview with some data topics as a guideline. Descriptive analysis was used to analize primary and secondary data. The result shows that earthquake and tsunami that happened in Simeulue District has destroyed facilities in marine and fisheries sector, include fishers victims. Steps in giving aid mechanism to the fishers at Simelue District; Choosing location for aid receiver and assistant group, arranging in phases that contents registers, re-registers, confirmation, administration and organization strenghten. Then, it was continued by capital strenghten, productive effort and network strenghten to the development phase. Assistance programe has been done successfully by the local fishers

\footnotetext{
* Peneliti Pada Balai Besar Riset Sosial Ekonomi Kelautan dan Perikanan, BRKP-DKP.

JI. KS TUBUN Petamburan VI Slipi Jakarta 10260. Telp. (021) 53650159
} 
that showed by two aspects : society response and economy aspect. The study suggests that donation or aid mechanism has to be considered with social-culture condition and customs in fishing, so that the aid can be useful for the fishers through need assessment process done quickly, exactly and directed.

\section{Key word : The Giving Aid Mechanism, Fisherman, Labuhan Bhakti}

\section{PENDAHULUAN}

Gempa bumi dan tsunami yang melanda Propinsi Nanggroe Aceh Darussalam dan Sumatera Utara (Nias) pada 26 Desember 2004 memberikan dampak yang luar biasa terhadap kehidupan masyarakat terutama masyarakat pesisir. Sedikitnya terdapat 164 ribu korban meninggal dan 114 ribu dinyatakan hilang. Disamping itu kerugian ditaksir mencapai trilyunan rupiah ( \pm 46 trilyun), yang mencakup hancurnya infrastruktur seperti jalan, jembatan dan bangunan (Anonimous 2006). Perkiraan luas penutup/ penggunaan lahan yang terpengaruh pada bencana tsunami dan gempa di Kabupaten Simeulue diperkirakan mencapai 28.195,9 Ha atau $13,3 \%$ dari total seluruh wilayah Kabupaten Simeulue (Anonimous, 2005).

Secara khusus tsunami berdampak besar terhadap kehidupan nelayan. Secara fisik kerugian akibat tsunami pada nelayan dapat dilihat dari rusak atau hilangnya kapal nelayan, rusaknya peralatan menangkap ikan (jaring, pancing,dll), peralatan pengolah ikan serta sarana dan prasarana yang terkait seperti TPI, darmaga, dan rumah nelayan. Faktor psikis yang ditimbulkan akibat tsunami antara lain adalah perasaan trauma nelayan untuk melaut, kehilangan harta benda dan rasa sedih akibat kehilangan sanak famili.

Banyaknya korban jiwa dan infrastruktur akibat tsunami membuat pemerintah negeri tetangga maupun negara lain untuk memberikan bantuan. Inventarisasi kerusakan sarana perikanan telah dilakukan diberbagai daerah dan bantuan kapal dan alat tangkap telah diberikan melalui bantuan international, pemerintah dan berbagai organisasi international non pemerintah (Wijopriono et al., 2007). Negara yang memberikan bantuan antara lain; Malaysia, Saudi Arabia, Turki, German, Canada, USA, Inggris, dan lain-lain. Selain bantuan dari pihak pemerintah ada juga bantuan yang diberikan oleh LSM/NGO (Lembaga Swadaya Masyarakat / Non Government Organization) dari dalam maupun luar negeri. LSM/NGO tersebut antara lain; Dompet Duafa, Save Children, Red Cross International, Rumah Zakat dll. Bantuan yang diberikan antara lain berupa makanan, pakaian, sarana kesehatan, maupun bantuan berupa kegiatan pembangunan seperti; rumah, jalan, dan bangunan.

Proses pemberian bantuan dapat dilakukan melalui berbagai cara yaitu secara langsung dan bertahap. Pemberian bantuan secara langsung diberikan sesuai dengan jenis bantuan yang tersedia, sebagai contoh; lembaga $X$ memberikan bantuan makanan sebanyak 100 paket kepada masyarakat di desa Y. Di lain pihak, bantuan bertahap diberikan melalui proses riset kebutuhan masyarakat setempat (need assessment). Kedua proses pemberian bantuan ini masingmasing memiliki kelebihan dan kekurangan. Proses pemberian bantuan langsung terkait dengan bantuan cepat tanggap seperti; makanan, pakaian dan obat-obatan. Bantuan bertahap terkait dengan pembangunan fasilitas fisik maupun penciptaan kesempatan kerja paska terjadinya bencana. Namun demikian, faktor terpenting dalam pemberian bantuan adalah bantuan harus diberikan tepat 
sasaran dan memikirkan faktor pemerataan.

Permasalahan yang sering terjadi dalam pemberian bantuan kepada masyarakat nelayan adalah bantuan tidak sampai ke nelayan (salah sasaran), bantuan tidak sesuai dengan kondisi alam dan kebiasaan nelayan (jenis dan bahan perahu berbeda), alat tangkap (jaring dan pancing) tidak sesuai dengan keahlian nelayan, bantuan tidak layak diberikan (mudah rusak). Hal ini dikarenakan pemberian bantuan tidak didasarkan akan kebutuhan, namun didasari oleh tersedianya bantuan oleh donatur, sehingga dalam pendistribusiannya mengalami kendala. Hal ini antara lain sebagai akibat kurangnya informasi jumlah korban bencana yang tepat untuk mendapatkan bantuan. Selain itu, banyak bantuan yang diberikan hanya mengejar kuantitas tetapi tidak menjaga kualitas, sehingga bantuan tidak bertahan lama.

Dibeberapa desa pesisir ditemukan fakta bahwa proses pemberian bantuan tidak merata, dimana ada desa yag mendapatkan bantuan secara berlebih, sedangkan desa yang lain tidak mendapatkan bantuan (Garces et al., 2006). Mencermati adanya masalah yang terjadi dalam pemberian bantuan kepada masyarakat nelayan, maka kegiatan pendugaan kebutuhan (need assessment) menjadi hal yang penting untuk dilakukan. Proses pendugaan kebutuhan (need assessment) kepada masyarakat nelayan harus sesuai prosedur yang telah ditetapkan, sehingga pemberian bantuan dapat tepat sasaran. Tulisan ini bertujuan menggambarkan mekanisme pemberian bantuan terhadap masyarakat nelayan setelah terjadinya gempa dan tsunami di Desa Labuhan Bhakti Kabupaten Simeulue, Propinsi Nangroe Aceh Darussalam (NAD).

\section{METODE}

\section{Lokasi dan Pendekatan Riset}

Riset dilakukan di Desa Labuhan Bhakti, Kecamatan Teupah Selatan, Kabupaten Simeulue, Propinsi NAD (Gambar
1). Pemilihan lokasi didasarkan beberapa kriteria yaitu: masukan dari Dinas Perikanan setempat, aspek penerimaan dan keterbukaan masyarakat terhadap peneliti yang melakukan riset, serta keberhasilan program yang diukur dari pencapaian fisik berupa: bangunan, jumlah kapal dan fasilitas lain.

Riset dilakukan menggunakan pendekatan studi kasus (case study) yang meneliti tentang status subyek penelitian yang berkenaan dengan suatu fase khas dari keseluruhan personalitas (Nazir 1988). Kasus yang dilihat adalah mekanisme pemberian bantuan kepada masyarakat nelayan setelah terjadinya bencana gempa bumi dan tsunami di wilayah Desa Labuhan Bhakti, Kecamatan Teupah Selatan, Kabupaten Simeulue, Propinsi NAD. Oleh karena itu, seperti halnya dengan penelitian kualitatif lainnya, penarikan kesimpulan hanya bisa dilakukan secara terbatas pada komunitas dan rentang waktu tertentu, dalam hal ini hanya terkait pada masyarakat tempat penelitian dilakukan. Untuk lingkup kehidupan sosial yang lebih luas, kesimpulan hasil studi ini hanya berlaku sebagai proposisi hipotetis (Yin, 1997).

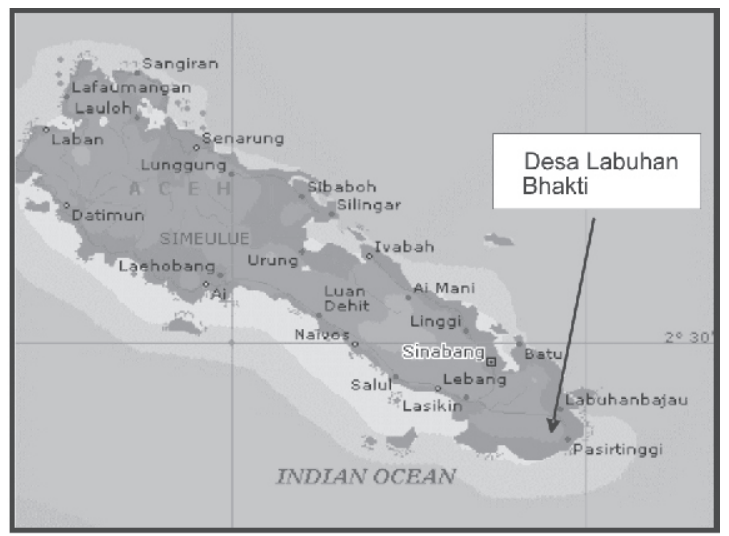

Gambar 1. Peta lokasi penelitian

Picture 1. The Reaserch Location Map

laporan yang terkait dengan bencana gempa bumi dan tsunami baik di Dinas Kelautan dan Perikanan setempat maupun lembaga lain.

Data primer yang dikumpulkan adalah 
berupa pengetahuan lokal masyarakat terkait dengan kejadian gempa bumi dan tsunami, mekamisme pemberian bantuan, termasuk kegiatan dalam pendampingan. Juga pengorganisasian yang terkait dengan pembinaan kelompok nelayan yang dilakukan dalam kaitannya dengan pemberian bantuan, pola bagi hasil, dan keberhasilan program baik secara ekonomi maupun besaran partisipasi masyarakat dan proses pendampingan yang dilakukan. Data sekunder yang dikumpulkan antara lain adalah data yang berkaitan dengan kerusakan sarana dan prasarana di sektor kelautan dan perikanan. Data dimaksud adalah kerusakan armada dan alat tangkap perikanan, kerusakan sarana pengolahan hasil perikanan, sarana perbenihan, dan tempat pelelangan ikan.

\section{Metode Pengumpulan Data}

Pengumpulan data dilakukan menggunakan pendekatan survei terhadap responden menggunakan cara wawancara semi terstruktur dengan panduan beberapa topik data seperti yang telah disebutkan pada jenis data yang diperlukan. Juga dilakukan observasi terhadap kondisi kehidupan responden guna mempertajam analisis dalam membahas hasil riset.

Penetapan contoh responden dilakukan menggunakan teknik purposive sampling, dimana sampel ditentukan berdasarkan kriteria-kriteria tertentu. Kriteria sampel ditetapkan pada nelayan penerima bantuan di Desa Labuhan Bhakti, Kecamatan Teupah Selatan, Kabupaten Simeulue Propinsi NAD. Kriteria tersebut meliputi nelayan penangkapan, anggota kelompok nelayan, pengurus kelompok nelayan, serta pendamping kelompok nelayan.

\section{Metode Analisis Data}

Data yang diperoleh baik data primer maupun data sekunder dianalisis secara deskriptif. Tujuannya adalah untuk menggambarkan kondisi masyarakat nelayan setelah bencana gempa dan tsunami dan kaitannya dengan proses pemberian bantuan.

\section{HASIL DAN PEMBAHASAN}

\section{Dampak Tsunami dan Pengetahuan Lokal Masyarakat}

Gempa bumi dan tsunami di Kabupaten Simelue berdampak terhadap rusaknya armada dan alat tangkap. Pada tabel 1 terlihat akibat yang ditimbulkan pada armada dan alat tangkap, antara lain; jumlah perahu tanpa motor yang mengalami rusak berat dan hilang sebanyak 403 unit. Perahu motor yang mengalami rusak ringan dan hilang sebanyak 581 unit. Kapal motor (3-5 GT) yang mengalami rusak ringan, rusak berat dan hilang sebanyak 42 unit. Kapal motor yang mengalami rusak ringan dan rusak berat sebanyak 5 unit. Kerusakan terhadap alat tangkap nelayan antara lain; jaring hilang sebanyak 433 unit, jala hilang sebanyak 110 unit, pancing hilang sebanyak 3.325 unit, rawai hilang sebanyak 44 unit, jermal/bagan hilang sebanyak 2 unit. Pukat pantai yang mengalami rusak ringan, rusak berat dan hilang sebanyak 7 unit. Bubu yang mengalami rusak ringan, rusak berat dan hilang sebanyak 24 unit.

Sementara pada tabel 2 terlihat pula dampak gempa bumi dan tsunami terhadap sarana pengumpulan dan pengolahan hasil laut serta prasarana kelautan, yaitu sebanyak 412 unit mengalami kerusakan. Secara detail kerusakan tersebut yaitu jemuran rusak ringan 38 unit, jemuran rusak berat 10 unit, jemuran hilang 52 unit dan cool box hilang 312 unit. Pabrik es yang mengalami rusak berat 1 unit dan rusak ringan 1 unit, BBI (balai benih ikan) yang mengalami rusak berat 1 unit, dermaga rusak berat 8 unit, rusak ringan 1 unit dan hilang 2 unit, TPI (tempat pelelangan ikan) hilang 1 unit, kantor koperasi kelautan rusak ringan 1 unit, rusak berat 2 unit dan hilang 2 unit. Boat latih 49 GT hilang 1 unit.

Rusaknya sarana dan infrastruktur perikanan di Simeulue membawa dampak 
Tabel 1. Kondisi Armada dan Alat Tangkap Setelah Tsunami Tahun 2004

Table 1. Condition of Fishing Fleets and Gears After Tsunami, 2004

\begin{tabular}{|c|c|c|c|c|c|}
\hline \multirow{2}{*}{ No } & \multirow{2}{*}{$\begin{array}{l}\text { Jenis Sarana Penangkapan/ } \\
\text { Type of Catch Facility }\end{array}$} & \multicolumn{3}{|c|}{$\begin{array}{l}\text { Jumlah Berdasarkan Tingkat Kerusakan/ } \\
\text { The Amount Based on Damage Levels }\end{array}$} & \multirow{2}{*}{$\begin{array}{l}\text { Jumlah/ } \\
\text { Total }\end{array}$} \\
\hline & & $\begin{array}{l}\text { Rusak Ringan/ } \\
\text { Small Damage }\end{array}$ & $\begin{array}{l}\text { Rusak Berat/ } \\
\text { Full Damage }\end{array}$ & $\begin{array}{l}\text { Hilang/ } \\
\text { Lost }\end{array}$ & \\
\hline \multicolumn{2}{|c|}{ Armada Tangkap/Vessels } & 75 & 317 & 639 & 1.031 \\
\hline 1 & $\begin{array}{l}\text { Perahu Tanpa Motor/ } \\
\text { Boat Without Engine }\end{array}$ & & 148 & 255 & 403 \\
\hline 2 & $\begin{array}{l}\text { Perahu Motor / } \\
\text { Boat With Engine }\end{array}$ & 51 & 152 & 378 & 581 \\
\hline 3 & $\begin{array}{l}\text { Kapal Motor / } \\
\text { Motor Boat 3-5 GT }\end{array}$ & 21 & 15 & 6 & 42 \\
\hline 4 & $\begin{array}{l}\text { Kapal Motor / } \\
\text { Motor Boat 6-10 GT }\end{array}$ & 3 & 2 & & 5 \\
\hline \multicolumn{2}{|c|}{ Alat Tangkap/Fishing Gear } & 9 & 10 & 3.939 & 3.958 \\
\hline 1 & Jala / Cast Net & & & 110 & 110 \\
\hline 2 & Jaring / Gill Net & & & 433 & 433 \\
\hline 3 & Pancing / Hook \& Line & & & 3.325 & 3.325 \\
\hline 4 & Pukat Pantai / Beach Seine & 3 & 3 & 1 & 7 \\
\hline 5 & Rawai / Longline & & & 44 & 44 \\
\hline 6 & Bubu / Trap & 6 & 7 & 24 & 24 \\
\hline 7 & Jermal / Bagan / Raft Net & & & 2 & 15 \\
\hline
\end{tabular}

Sumber/Source:Anonimous, 2006

Tabel 2. Dampak Tsunami Terhadap Prasarana Kelautan dan Pengolahan Ikan Tahun 2004

Table 2. The Impact of Tsunami on Fisheries Infrastructure and Fish Processing 2004

\begin{tabular}{|c|c|c|c|c|c|}
\hline \multirow{2}{*}{ No } & \multirow{2}{*}{$\begin{array}{c}\text { Jenis Sarana } \\
\text { Penangkapan/ } \\
\text { Type of Fishing Facility }\end{array}$} & \multicolumn{3}{|c|}{$\begin{array}{c}\text { Jumlah Berdasarkan Tingkat Kerusakan / } \\
\text { The Amount Based On Damage Levels }\end{array}$} & \multirow{2}{*}{$\begin{array}{l}\text { Jumlah/ } \\
\text { Total }\end{array}$} \\
\hline & & $\begin{array}{l}\text { Rusak Ringan/ } \\
\text { Small Damage }\end{array}$ & $\begin{array}{l}\text { Rusak Berat/ } \\
\text { Full Damage }\end{array}$ & Hilang/Lost & \\
\hline & Pengolahan Hasil Laut / Fish & Procesing & & & \\
\hline 1 & Jemuran / Drying Facility & 38 & 10 & 52 & 100 \\
\hline \multirow[t]{2}{*}{2} & $\begin{array}{l}\text { Kotak Pendingin / } \\
\text { Cool Box }\end{array}$ & & & 312 & 312 \\
\hline & $\begin{array}{l}\text { Sub Jumlah / Sub Total } \\
\text { Prasarana / Facility }\end{array}$ & 38 & 10 & 364 & 412 \\
\hline 1 & $\begin{array}{l}\text { BBI / The Government } \\
\text { Hatchery }\end{array}$ & & 1 & & 1 \\
\hline 2 & Pabrik Es / Ice Factory & 1 & 1 & & 2 \\
\hline 3 & Dermaga / Pier & 1 & 8 & 2 & 11 \\
\hline 4 & Tpi / Fish Landing Pier & & & 1 & 1 \\
\hline 5 & $\begin{array}{l}\text { Kantor Koperasi Kelautan / } \\
\text { Marine Cooperation Office }\end{array}$ & 1 & 2 & 2 & 5 \\
\hline 6 & $\begin{array}{l}\text { Kapal Latih/ } \\
\text { Training Boat (49 Gt) }\end{array}$ & & & 1 & 1 \\
\hline & Sub Jumlah/Sub Total & 3 & 12 & 6 & 21 \\
\hline
\end{tabular}

Sumber/Source: Anonimous, 2006 
terhadap kehidupan nelayan. Kondisi ini membuat nelayan tidak bisa pergi ke laut untuk mencari ikan. Nelayan banyak menganggur di tenda pengungsian dikarenakan tidak punya keahlian untuk beralih pekerjaan lain. Dalam hal ini, kondisi Simeulue setelah diterjang gempa bumi dan tsunami adalah sama dengan daerah lainnya seperti di Banda Aceh, Meulaboh, Calang; bangunan hancur, kapal rusak dan prasarana infrastruktur lainnya mengalami kerusakan. Namun, ditengah kehancuran infrastruktur di Kabupaten Simeulue terdapat kondisi yang sangat berbeda dengan daerah yang lain, yakni sedikitnya korban jiwa. Menurut peta perkiraan korban jiwa serta kerusakan infrastruktur perikanan paska tsunami (Soebandono dan Budiman, 2006) menyebutkan terdapat 7 orang korban jiwa di Kabupaten Simeulue. Jumlah korban ini jauh lebih sedikit jika dibandingkan dengan kondisi Banda Aceh yang agak jauh dari pusat gempa dan menimbulkan jumlah korban yang banyak sekitar 3384 orang. Diperkuat dengan laporan Anton Alifandi seorang wartawan BBC siaran Indonesia yang menyatakan dari total penduduk 78.000 jiwa di Pulau Simeulue, hanya tujuh orang yang meninggal dunia, sementara di Aceh daratan sampai ratusan ribu orang tewas dihantam tsunami (http//:www.bbc.co.uk). Kondisi seperti ini tentu saja menimbulkan pertanyaan berbagai pihak karena letak Kabupaten Simeulue cenderung lebih dekat dengan pusat gempa, namun hanya sedikit korban jiwa sedangkan daerah lain yang agak jauh dari pusat gempa banyak memakan korban.

Sedikitnya korban jiwa yang berjatuhan pada Kabupaten Simeulue menarik pihak luar negeri. Setidaknya hal itu yang melatar belakangi pemberian penghargaan (UNSasakawa Award) atas kewaspadaan dini rakyat Simeulue terhadap bahaya Tsunami/Smong akibat gempa 26 Desember 2004) yang diberikan melalui Bupati Simeulue pada hari Rabu (12/10/05) di Bangkok
Thailand (http.www.serambinews.com).

Jika melihat sejarah, dahulu pernah terjadi tsunami di Simeulue pada tahun 1907 (Soebandono dan Budiman, 2006). Saat itu terjadi kerusakan yang parah dan menimbulkan jatuhnya korban jiwa yang tidak sedikit. Hal inilah yang menimbulkan trauma psikis dan jiwa kepada penduduk di Simeulue sehingga memberikan bekas luka yang sulit untuk dilupakan. Sejak saat itu tsunami telah dikenal oleh masyarakat di Pulau Simeulue. Tsunami mendapat istilah oleh penduduk asli dengan sebutan "SMONG" (berarti ombak yang menggulung). Diantara banyaknya korban jiwa yang berjatuhan, ada juga korban yang selamat dari musibah tersebut. Korban yang selamat ini menjadi saksi hidup atas kejadian yang pernah dialami. Semenjak saat itulah cerita tsunami dengan istilah "SMONG" mulai disampaikan secara turun temurun. Secara garis besar ceritanya adalah "jika dihari kelak terjadi gempa bumi kemudian disusul dengan menyusutnya air laut dari pinggir pantai, maka berlarilah kearah gunung dan jangan mempedulikan harta benda yang ada dirumah, ajaklah keluargamu turut serta dan jangan tergoda untuk mengambil ikan dipinggir pantai walaupun terdapat banyak ikan". Hal inilah menjadi pengetahuan lokal masyarakat setempat yang diperkirakan dapat berguna bagi masyarakat setempat terutama kaitannya dengan kesadaran akan adanya bencana tsunami di sekitar mereka.

Selain pengetahuan lokal tersebut, kondisi topografi Pulau Simeulue memungkinkan penduduk untuk menyelamatkan diri dari tsunami. Dr Rahman Hidayat, anggota Tim Survey Internasional, secara khusus meneliti Pulau Simeulue setelah tsunami dan dua gempa yang melanda pulau ini dalam waktu dua tahun. "Dari fakta di lapangan dapat dilihat bahwa hanya 200 hingga 300 meter dari garis pantai sudah perbukitan, sehingga sebagai jalur menghindari mereka lebih baik dibanding di Meulaboh, Calang, atau di Lhok Nga," kata Dr. 
Rahman Hidayat. Dengan demikian maka waktu yang dibutuhkan para penduduk Pulau Simeulue untuk menyelamatkan diri relatif lebih pendek dari beberapa wilayah lainnya (http//:www.bbc.co.uk).

\section{Mekanisme Pemberian Bantuan dan Pendampingan}

Penentuan Desa Penerima Bantuan Proses penentuan desa penerima bantuan ditentukan oleh tim yang melakukan need assessment dengan kriteria yang telah di tetapkan. Pembentukan tim tergantung dari kebijakan pemberi bantuan. Anggota tim dapat terdiri dari atas perwakilan dinas perikanan setempat, perwakilan pemberi bantuan atau tim independent yang ditunjuk oleh Donor. Kriteria yang ditetapkan dalam menentukan desa bermacam-macam, antara lain; kerusakan yang ditimbulkan, akses lokasi, lokasi dengan karakter tertentu (desa

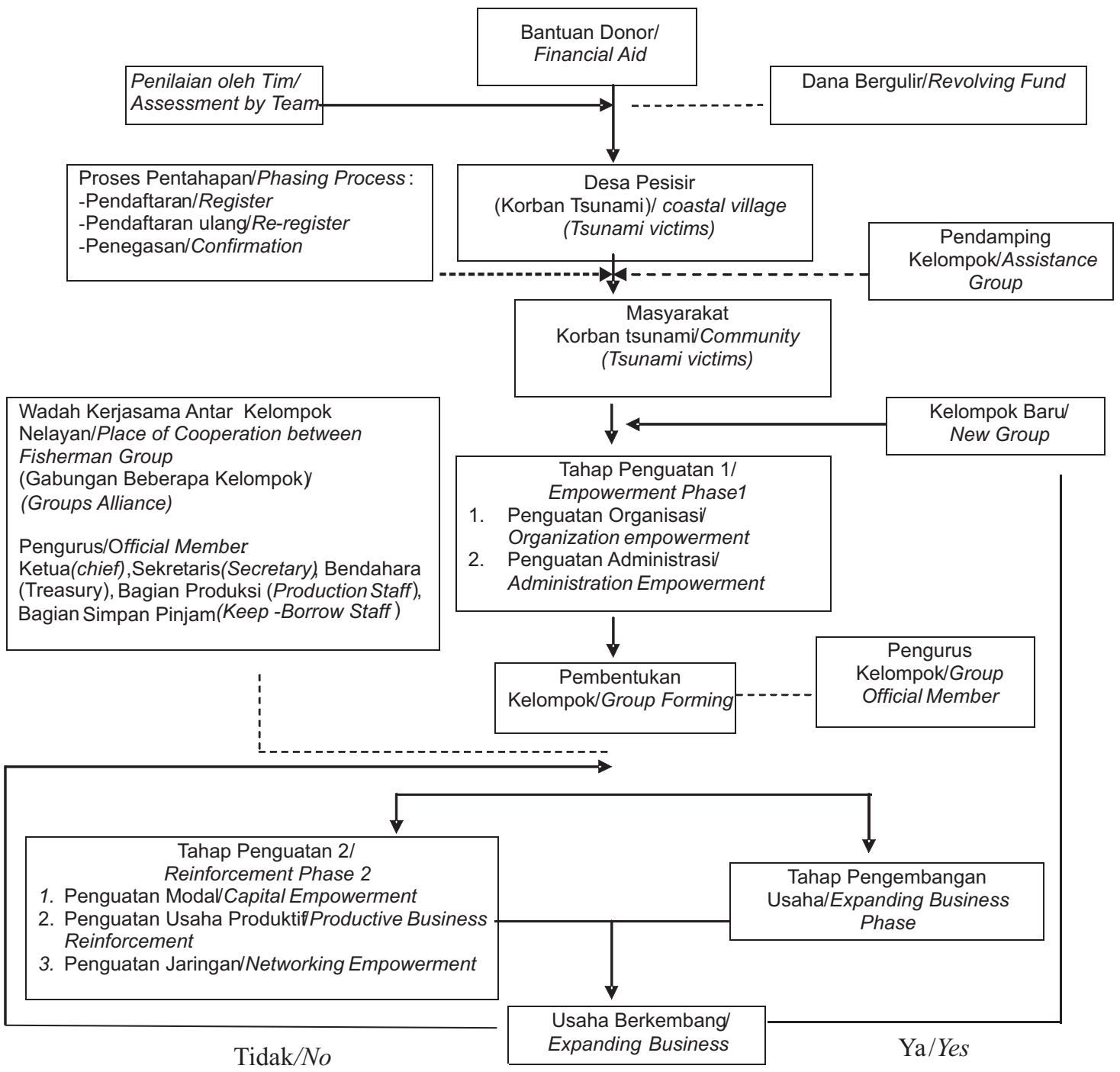

\section{Gambar 2. Mekanisme Pendampingan dan Pembentukan Kelompok Nelayan} Picture 2. Assisstence and Formation Fishers Groups Mechanism 
perikanan atau pertanian), penerimaan warga, jenis bantuan yang akan diberikan. Setelah sampling kebutuhan telah dilakukan dibeberapa desa maka keputusan penetapan lokasi desa menjadi kewenangan tim. Langkah-langkah yang ditempuh untuk melakukan tahapan pendampingan dan pembentukan kelompok nelayan dapat dilihat pada gambar 2 .

\section{Pendampingan dan Penentuan Kelompok}

Setelah desa penerima bantuan telah ditetapkan maka proses selanjutnya yang harus dilakukan adalah pembentukan pendamping kelompok. Pendamping kelompok tidak berasal dalam satu desa melainkan dari daerah lain. Hal ini ditujukan agar tidak menjadi konflik kepentingan bagi pendamping kelompok dan jenis bantuan yang akan diberikan. Pendamping kelompok merupakan orang yang memiliki keahlian lebih dibandingkan dengan masyarakat setempat. Kriteria pendamping kelompok antara lain; berkemauan keras, mudah bersosialisasi, memiliki kemampuan managerial, mampu melihat potensi orang lain, mengerti adat dan budaya lokal, dan mau menetap dilokasi. Kriteria ini penting untuk dipenuhi sehingga program pendampingan dapat berjalan sesuai rencana yang telah ditetapkan.

Proses penentuan kelompok dilakukan oleh pendamping desa dan tim penentu desa. Pada tahap awal dilakukan sosialisasi program di desa untuk menjelaskan kepada masyarakat tentang kegiatan pemberian bantuan. Pada tabel 3 dapat terlihat fluktuasi jumlah masyarakat yang terlibat dalam kegiatan. Pada proses pendaftaran terdaftar sebanyak 200 orang. Banyaknya masyarakat yang mendaftar dapat dimaklumi karena mereka mengharapkan untuk mendapatkan bantuan. Pada tahap ini dijelaskan bahwa bantuan merupakan dana bergulir dan bukan hibah. Hal ini sengaja dilakukan untuk mengubah pola pikir masyarakat sehingga tidak menjadi malas dan hanya mengharapkan datangnya bantuan. Pada pola pemberian bantuan secara bergulir dijelaskan bahwa masyarakat diasumsikan berhutang dan diwajibkan melunasi kewajiban secara menyicil setiap bulannya. Setelah pendaftar diseleksi dengan kriteria yang telah ditetapkan oleh donor (bantuan khusus untuk nelayan tangkap) maka dilakukan pendaftar ulang dan tersaring sebanyak 138 orang. Jumlah ini kemudian menyusut menjadi 78 orang setelah masyarakat mengikuti pengarahan yang dilakukan oleh tim mengenai mekanisme pemberian bantuan.

\section{Penguatan Organisasi dan Administrasi}

Kegiatan penguatan pertama berfokus pada penguatan organisasi dan penguatan administrasi. Penguatan organisasi dilakukan dengan cara mengenalkan dan membentuk susunan organisasi awal masyarakat calon penerima bantuan seperti pembentukan ketua, sekertaris dan bendahara. Masyarakat diajarkan bagaimana terlibat dalam sebuah rapat, bagaimana memimpin rapat, mengeluarkan pendapat, menghargai pendapat, izin keluar ruangan pada saat rapat, membuat notulen rapat dan mengambil keputusan secara musyawarah. Penguatan organisasi penting dilakukan sebagai sarana memperkenalkan masyarakat terhadap arti sebuah lembaga sehingga masyarakat merasa memiliki serta bertangung jawab untuk mengembangkannya. Proses ini merupakan tahapan yang berat karena harus merubah pandangan (mind-set) masyarakat dari pengambilan keputusan perseorangan menjadi keputusan bersama yang harus ditaati semua pihak. Selain itu, pada tahapan ini juga menyadarkan masyarakat tentang hak dan kewajiban dalam berorganisasi.

Penguatan administrasi dilakukan untuk menyadarkan masyarakat akan pentingnya informasi yang tercatat dalam pembukuan sederhana. Masyarakat diajarkan bagaimana mengelola sebuah pembukuan, mencatat perputaran uang, mencatat barang inventaris 
serta mencatat jumlah anggota kelompok yang terlibat. Proses ini juga sulit dilakukan mengingat tingkat pendidikan mereka rendah sehingga mempunyai keterbatasan dalam hal kebiasaan membaca dan menulis. Selain itu merubah pola pikir masyarakat dari keacuhan dalam pencatatan menjadi sebuah kepedulian terhadap administrasi. Pada tabel 3 terlihat bahwa selama mengikuti tahap penguatan organisasi dan penguatan administrasi ditemukan berbagai respon dari masyarakat yang mengikuti program. Ada masyarakat yang semangat, acuh, bahkan tidak melanjutkan kegiatan karena merasa jenuh atau kesulitan untuk merubah cara pandang dalam berorganisasi. Hal ini secara tidak langsung menjadi seleksi alam dalam penentuan penerima bantuan. Setelah melewati tahap ini jumlah masyarakat yang masih bertahan sebanyak 42 orang.

\section{Pembentukkan Kelompok}

Pembentukan kelompok dilakukan melalui dinamika organisasi yaitu melakukan penggantian pengurus bayangan yang telah dibentuk dengan pengurus yang baru. Pergantian ini penting untuk dilakukan untuk melakukan pergantian suasana baru dalam kelompok. Pemilihan pengurus didasarkan dari pemantauan potensi peserta selama mengikuti kegiatan penguatan organisasi dan administrasi. Dalam hal ini anggota kelompok yang menentukan pengurus melalui mekanisme musyawarah.

Jumlah kelompok yang dibentuk dari jumlah masyarakat yang bertahan mengikuti program (42 orang) adalah dua kelompok yaitu Cahaya Rezeki dan Rezeki Bersama. Tiap kelompok terdiri dari $20-22$ orang. Tiap kelompok diberikan 10 buah perahu dengan kapasitas masing-masing dua orang. Perahu itu menjadi milik pribadi dengan cara dicicil setiap penangkapan dengan kondisi tidak mengalami kerugian.

\section{Penguatan Modal, Usaha dan Jaringan}

Tahapan penguatan kedua terdiri dari penguatan modal, penguatan usaha produktif dan penguatan jaringan. Tahap penguatan modal dilakukan setelah melakukan pembentukan kelompok dan Wadah Kelompok Antar Nelayan (WKAK). Tahap penguatan modal dilakukan dengan cara menghimpun modal awal dari nelayan sebesar Rp 50.000,00 dan dapat dicicil setiap bulan. Penghimpunan modal ini berfungsi sebagai metode mengikat nelayan agar bersungguhsungguh dalam menggunakan bantuan dan tidak menyiakannya. Selain itu ada pembayaran cicilan kapal dan alat tangkap sebesar Rp 5000,00 yang wajib dicicil oleh nelayan selama 5 tahun dengan syarat jumlah

\section{Tabel 3. Jumlah Nelayan yang Mengikuti Tahapan Kegiatan}

Table 3. Number of Fishers in Each Stage of Action

\begin{tabular}{clc}
\hline No & Pentahapan/Reinforcement & $\begin{array}{c}\text { Jumlah Nelayan (orang)/ } \\
\text { Fisherman Number }\end{array}$ \\
\hline 1 & Pendaftaran / Register & 200 \\
2 & Pendaftaran Ulang / Re- register & 138 \\
3 & Penegasan / Confirmation & 78 \\
4 & Pembentukan / Forming & 42 \\
5 & Pengembangan / Development & 62 \\
\hline
\end{tabular}


hasil tangkapan> Rp 50.000,00. Jika hasil tangkapan nelayan < Rp 50.000, maka nelayan tidak wajib untuk mencicil. Nelayan juga dikenalkan budaya menabung dengan memfasilitasi tabungan sukarela yang dapat diambil sewaktu nelayan membutuhkan. Besarnya tabungan sukarela bervariasi yaitu; Rp 2000,00 -Rp 50.000,00 setiap melakukan penangkapan.

Penguatan usaha produktif dilakukan dengan cara menjual BBM (Bahan Bakar Minyak), dan es yang digunakan oleh nelayan setiap kali akan berangkat kelaut. Penjualan bbm dan es tidak hanya kepada nelayan anggota kelompok tetapi dijual juga kepada nelayan yang bukan anggota kelompok. Selain itu nelayan mendapatkan pinjaman tanpa bunga yang hanya diperuntukan membeli rokok atau umpan pancing pada saat akan melakukan penangkapan. Mekanisme pengembalian pinjaman bermacam-macam. Untuk pembayaran hutang BBM dan uang non bunga dikembalikan maksimal dalam satu minggu, sedangkan pembayaran es harus dibayarkan setelah melakukan penangkapan. Keterikatan nelayan yang menjadi anggota kelompok adalah wajib menjual hasil tangkapan ikan ke kelompok. Salah satu fungsi WKAK adalah membeli ikan hasil tangkapan nelayan kemudian menjual ke pasar. Ikan hasil tangkapan nelayan dibeli dengan harga Rp 8.000,00 per kg dan dijual ke pasar atau pembeli lain seharga Rp 10.000,00. Keuntungan tiap kg sebesar Rp 2.000,00 dijadikan sebagai keuntungan kelompok dan dibagikan pada saat perhitungan bagi hasil.

Tahapan penguatan jaringan dilakukan dengan cara melibatkan anggota kelompok secara aktif untuk mengenalkan dengan jaringan yang terkait dengan usaha penangkapan, seperti mengenalkan jaringan pemasaran dan birokrasi. Pengenalan jaringan pemasaran dilakukan secara langsung kepada perwakilan kelompok dengan cara berkunjung kelokasi pemasaran seperti: Sinabang (Kabupaten Simeulue), Sibolga (Propinsi Sumatera Utara) dan Singkil (Aceh daratan). Pada saat itu nelayan dikenalkan dengan calon pembeli yang siap menampung hasil tangkapan dan dijelaskan mengenai rantai pemasaran serta harga yang terkait dengan hasil tangkapan. Selain itu dijelaskan pentingnya menjaga kondisi tangkapan untuk tetap hidup agar nilai jual meningkat.

Disamping mengenalkan pembeli dan proses pengiriman barang, nelayan diberikan pelatihan pembuatan kapal berbahan kayu di Pulau Jawa. Pelatihan ini berguna bagi nelayan sehingga dapat mandiri dalam hal pembuatan kapal dan tidak tergantung dengan daerah lain. Nelayan juga diajarkan membuat kapal berbahan viber dan mengenalkan toko yang khusus menjual bahan tersebut di Medan.

Untuk pengenalan jaringan birokrasi, nelayan diantarkan untuk bertemu dengan dinas perikanan kelautan setempat dan BRR Aceh-Nias (Badan Rekonstruksi dan Rehabilitasi) untuk melakukan audiensi. Kegiatan ini berguna bagi nelayan sebagai pembelajaran agar dapat menyalurkan aspirasi ke instansi resmi maupun pemerintahan. Disamping bermanfaat bagi nelayan, kegiatan ini bermanfaat bagi dinas terkait sehingga penyaluran aspirasi masyarakat tidak harus melalui demonstrasi yang berbau anarkis tetapi melalui aspirasi yang disampaikan secara damai.

\section{Wadah Kelompok Antar Nelayan (WKAK)}

WKAK merupakan sebuah lembaga yang mewadahi kumpulan dari kelompokkelompok nelayan. Tujuan wadah ini dibentuk adalah mengkoordinasikan kegiatan nelayan dalam hal usaha penangkapan, melakukan pengawasan dan manajemen terhadap kelompok yang ada, serta bertanggung jawab terhadap mekanisme pemasaran hasil tangkapan nelayan. 
Pada awalnya, nelayan melakukan kegiatan administrasi pencatatan hasil tangkapan ikan dengan sistem piket bergilir. Metode ini bertujuan untuk memberikan pemahaman kepada nelayan akan pentingnya informasi data tangkapan sekaligus melatih dalam hal administrasi. Namun dikarenakan ada kendala terkait dengan tingkat pendidikan dan kemampuan nelayan untuk menulis membuat kegiatan pencatatan hasil tangkapan tidak dilakukan oleh nelayan melainkan pengurus WKAK. Tugas nelayan terkait proses penangkapan ikan, sedangkan administrasi merupakan tugas WKAK.

Mekanisme pengawasan yang dilakukan oleh WKAK adalah melakukan koordinasi secara langsung dengan pengurus kelompok. Pengurus kelompok melakukan koordinasi dengan anggota kelompok.

\section{Pola Bagi Hasil}

Pada gambar 3 terlihat skema pola bagi hasil yang dilakukan nelayan anggota kelompok dengan WKAK. Bagi hasil dilakukan pada saat nelayan selesai melakukan penangkapan. Nelayan anggota kelompok wajib menjual hasil tangkapan kepada WKAK. Demikian pula halnya dengan WKAK wajib membeli hasil tangkapan nelayan anggota. Hasil tangkapan dibeli oleh WKAK seharga Rp 8.000,00 per $\mathrm{kg}$ kemudian WKAK menjual kembali ke pembeli atau pasar dengan harga Rp 10.000,00 per kg. Setelah hasil tangkapan dibeli oleh WKAK maka hasil tersebut dikenakan potongan dari pembelian bbm dan es. Untuk harga bbm per liter sebesar Rp $7.000,00$ dan harga es per $\mathrm{kg} \operatorname{Rp} 1.000,00$. Setelah hasil dikurangi untuk membayar BBM dan es maka hasil harus dibagi menjadi dua bagian. Sehingga setiap nelayan

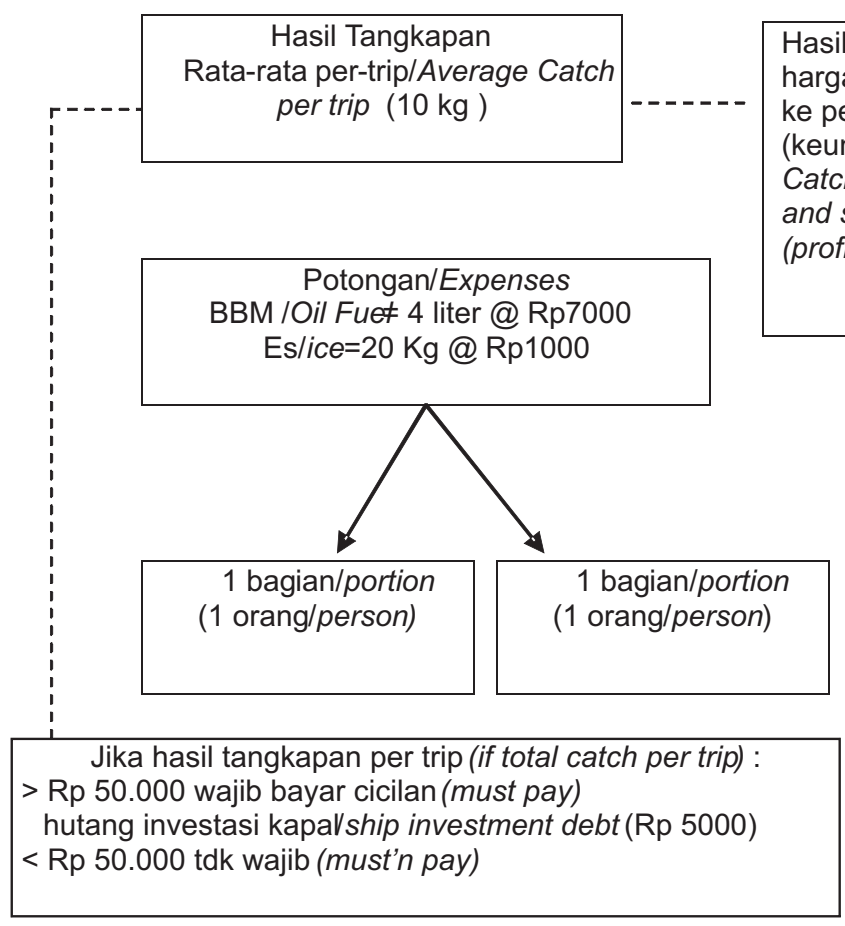

Gambar 3. Skema Pola Bagi Hasil

Figure 3. Sharing System Scheme 
mendapatkan hasil sebesar 1 bagian sesuai dengan hasil tangkapannya.

Sebagai contoh jika dalam satu kapal mendapatkan hasil sebanyak $10 \mathrm{~kg}$ maka nilai tangkapannya adalah 10 x Rp 8.000,00 yaitu sebesar $R p 80.000,00$. hasil tersebut dipotong biaya produksi untuk membeli es dan BBM ((4 x 7000)+(20 x 1000)) sebesar Rp 48.000,00. Hasil yang didapatkan nelayan adalah $\mathrm{Rp}$ $32.000,00$. Kemudian hasil tangkapan dibagi menjadi dua bagian, masing-masing mendapatkan $\operatorname{Rp} 16.000,00$.

\section{Sisa Hasil Usaha (SHU)}

Sisa Hasil Usaha (SHU) nelayan dihitung pada kurun waktu satu tahun sekali. Pengurus WKAK melakukan perhitungan SHU berdasarkan keaktifan kelompok nelayan dalam melakukan proses produksi. Semakin banyak melakukan pembelian BBM dan es maka keuntungan yang akan diperoleh menjadi semakin besar. Demikian halnya dengan semakin meningkatnya hasil tangkapan ikan akan berpengaruh terhadap pendapatan SHU.

Pada gambar 4 terlihat mekanisme pembagian shu kepada nelayan. Proporsi keuntungan yang diberikan WKAK dari keuntungan penjualan es dan BBM kepada nelayan adalah 2\%, sedangkan $98 \%$ dipergunakan sebagai dana cadangan yang dikelola oleh WKAK. Selain itu, nelayan mendapatkan keuntungan dari setiap penjualan ikan selama satu tahun sebesar $2 \%$. Pengurus kelompok mendapatkan 3\%. Untuk keuntungan sebesar 95\% dipergunakan sebagai dana cadangan yang dikelola oleh kelompok.

\section{Keberhasilan Program bantuan}

\section{Partisipasi Masyarakat}

Salah satu kunci keberhasilan kegiatan pendampingan ini adalah adanya partisipasi dan peranan masyarakat dalam menentukan proses yang akan dilalui untuk mencapai tujuan yang telah ditetapkan. Tahapan yang utama adalah menyadarkan masyarakat bahwa sukses atau tidaknya program tergantung dari masing-masing pihak sehingga menjadi memiliki tanggung jawab bersama. Untuk menumbuhkan partisipasi maka kegiatan yang akan dilakukan merupakan kebutuhan yang diinginkan masyarakat.

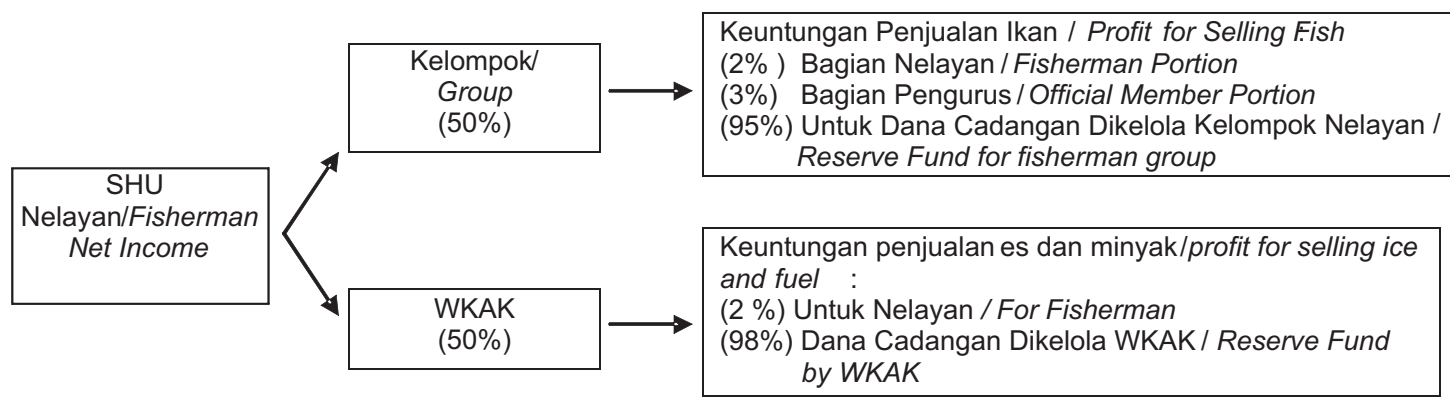

\section{Gambar 4. Mekanisme Pembagian Sisa Hasil Usaha}

Figure 4. SHU Mechanism 


\section{Pendampingan yang Berkelanjutan}

Pendampingan terhadap masyarakat dilakukan secara bertahap dan menyeluruh. Masyarakat disadarkan untuk maju dan berkembang tidak tergantung dengan bantuan dari pihak lain (NGO/Gov) serta dijauhkan dari pemahaman untuk meminta-minta. Pendampingan dilakukan dengan cara mengubah mind-set masyarakat terkait dengan pemberian bantuan bencana. Masyarakat diberikan pemahaman secara adminsitrasi, teori dan praktek sehingga pemberian bantuan tidak hanya diberikan tetapi masyarakat mengetahui proses yang telah dan akan dilakukan sehingga menciptakan masyarakat yang mandiri.

\section{Respon Masyarakat}

Ukuran yang dapat dijadikan tolak ukur keberhasilan sebuah program memiliki standar yang bervariasi diantaranya respon masyarakat. Respon masyarakat dapat dilihat dari jumlah masyarakat yang mengikuti program sejak pendaftaran hingga program berjalan. Selain itu respon masyarakat dapat dilihat dari keterlibatan dalam sebuah program. Semakin banyak masyarakat yang terlibat maka dapat dikatakan sebagai respon positif sedangkan jika jumlah masyarakat yang terlibat sedikit, maka respon negatif. Perubahan cara pandang masyarakat tentang suatu program merupakan sebuah respon. Jika perubahan sesuai dengan tujuan program dapat dikatakan respon positif dan jika tidak ada perubahan terkait dengan program maka respon negatif.

Respon masyarakat di lokasi penelitian dapat dikatakan positif. Hal ini dapat dilihat dari jumlah masyarakat yang mengikuti program pada saat pendaftaran sebanyak 200 orang, walaupun mengalami penurunan seiring adanya proses seleksi alam menjadi 40 orang. Namun pada saat pengembangan program, jumlah masyarakat yang terlibat meningkat menjadi 62 orang, pada tabel 3. Hal ini mengindikasikan adanya keberhasilan program dilihat dari menigkatnya jumlah masyarakat yang terlibat

Dilihat dari perubahan cara pandang masyarakat terhadap program dapat dinilai positif. Hal ini terlihat dari antusiasme keterlibatan masyarakat dalam program. Mereka merasa yakin bahwa kehidupan akan semakin membaik seiring keterlibatan dengan program ini. Hal ini dikarenakan saat ini mereka telah memiliki penghasilan dari hasil menangkap ikan dan tidak perlu khawatir merugi sebab ikan hasil tangkapan sudah dipastikan ada yang membeli. Ketika dilakukan wawancara masyarakat tidak mengharapkan bantuan kepada pihak yang datang ke lokasi tetapi terlihat ada perubahan pola pikir masyarakat bahwa mereka sanggup menjadi mandiri mengahadapi situasi sulit setelah tsunami.

\section{Aspek Ekonomi}

Keberhasilan aspek ekonomi terlihat dari bertambahnya jumlah kapal yang dimiliki oleh kelompok. Pada awal program jumlah kapal motor yang dimiliki sebanyak 20 unit sedangkan hampir satu tahun program berjalan jumlah kapal meningkat menjadi 25 unit. Selain itu terdapat peningkatan nilai modal yang dimiliki. Modal awal yang dimiliki sebanyak Rp 500.000,- kemudian meningkat menjadi Rp 2.500.000,-. Peningkatan terjadi dari hasil keuntungan penjualan ikan hasil tangkapan nelayan dan penjualan BBM.

Setelah terjadi tsunami banyak nelayan kehilangan pekerjaan. Hal ini dikarenakan rusaknya peralatan menangkap ikan dan ketidakmampuan nelayan untuk beralih pekerjaan karena tidak memiliki keahlian selain menangkap ikan. Setelah mengikuti program pendampingan, masyarakat memiliki penghasilan dari hasil menangkap ikan. Hasil yang dibawa pulang nelayan setiap melakukan penangkapan ikan bervariasi tergantung dengan jumlah tangkapan dan jenis ikan, ratarata penghasilan yang dibawa pulang adalah Rp 25.000,- sampai Rp 50.000,-. Walaupun 
nilai ini terbilang kecil, namun hal ini jauh lebih baik dibandingkan kondisi pada saat setelah tsunami dimana nelayan tidak memiliki penghasilan. Adanya perubahan menuju kondisi lebih baik pada saat sebelum dan sesudah mengikuti program mengindikasikan bahwa program tersebut bernilai positif. Dilain pihak jika tidak terdapat perubahan menuju kondisi lebih baik bahkan cerderung memburuk maka dapat dikatakan program bernilai negatif.

\section{KESIMPULAN DAN SARAN}

Gempa bumi dan tsunami yang terjadi di Kabupaten Simeulue telah mengakibatkan rusaknya sarana dan fasilitas di sektor kelautan dan perikanan, bahkan korban jiwa pada masyarakat nelayan. Pemberian bantuan kepada masyarakat nelayan di Kabupaten Simeulue melalui beberapa tahapan, mulai dari menentukan lokasi penerima bantuan dan kelompok pendamping, hingga pentahapan yang berupa kegiatan pendaftaran, pendaftaran ulang dan penegasan. Kemudian dilanjutkan dengan kegiatan penguatan organisasi dan administrasi. Output dari proses penguatan1adalah terbentuknya kelompok penerima bantuan. Proses selanjutnya adalah penguatan modal, usaha produktif dan penguatan jaringan menuju tahap pengembangan usaha. Jika usaha berkembang maka dibentuk kelompok baru, namun jika tidak berkembang tetap dilakukan tahap penguatan usaha dan jaringan, menuju pengembangan usaha.

Program pendampingan telah berhasil dilakukan pada nelayan setempat yang ditunjukkan oleh dua aspek yaitu respon masyarakat dan aspek ekonomi. Dilihat dari respon masyarakat disimpulkan bahwa nelayan setempat memiliki respon yang tinggi terhadap program. Jika dilihat dari aspek ekonomi terjadi peningkatan pendapatan nelayan setelah tsunami menjadi Rp 25.000,sampai $R p$ 50.000,- setiap melakukan penangkapan.

Berdasarkan hasil riset ini, maka disarankan bahwa proses pemberian bantuan terhadap nelayan hendaknya memperhatikan kondisi sosial budaya, adat dan kebiasaan dalam menangkap ikan, sehingga bantuan dapat berguna bagi nelayan. Proses need assessment harus dilakukan secara cepat, tepat dan terarah sehingga bantuan yang diberikan sesuai dengan kebutuhan masyarakat pada saat itu dan tidak sia-sia. Untuk pemberian bantuan dengan term waktu yang panjang dibutuhkan program pendampingan terhadap masyarakat penerima bantuan. Proses pendampingan harus mampu merubah pemikiran (mind-set) masyarakat untuk menjadi mandiri dan tidak tergantung dengan program bantuan dan keberadaan pendamping.

\section{DAFTAR PUSTAKA}

Anton Alifandi. Sistem Deteksi Sunami yang Efektif. Http://www.bbc.co.uk/ indonesian/programmes/story/2007/02/ 070213_simeleu.shtml (1 September 2007)

Balai Besar Riset Sosial Ekonomi. 2006. Laporan Akhir PRA (Participatory Rural Appraisal) Sosek. Balai Besar Riset Sosial ekonomi Kelautan dan Perikanan bekerjasama dengan Unit Pelaksanan Rehabilitasi dan Pengelolaan Terumbu Karang -Tahap II. Direktorat Jenderal Pesisir dan Pulau-Pulau Kecil. Jakarta: BBRSE.

Garces, L., A.Tewfik, M. Pido, N. Fatan, D. Adhuri, N. Andrew and M. M. Dey. 2006. Fisheries Rehabilitation In Post-Tsunami Aceh: Status and Needs From Participatory Consultative Workshop. Naga 29(3): 15-30.

Nan, Tindaklanjuti Sasaka Award Bupati Simeulue Keluarkan Buku Tsunami. Http://www.serambinews.com/. html (26 07 - 2007) 
Nazir, M. 1988. Metode Penelitian. Jakarta: Ghalia Indonesia. 622 hal.

Pemerintah Daerah Propinsi Nanggroe Aceh Darussalam. 2005. Rencana Induk Rehabilitasi dan Rekonstruksi Wilayah Aceh dan Nias, Sumatera Utara, Buku I : Rencana Bidang Tata Ruang dan Pertanahan.

Subandono, D dan Budiman 2006.Tsunami. Bogor: Sarana Komunikasi Utama. 300 hal
Wijopriono, B.Sumiono, B.Sadhotomo, dan Wudianto 2007. Mengungkap Dampak Tsunami terhadap Sumberdaya Perikanan: Hasil-Hasil dari Ekspedisi Paska Tsunami 2005-2006. Dipresentasikan pada Simposium Nasional Riset Kelautan dan Perikanan. Hotel Bumi Karsa - Bidakara, Jakarta. Selasa, 7 Agustus 2007.

Yin, Robet. K. 1997. Studi Kasus (Desain dan Metode). Jakarta: PT. Raja Grasindo Persada. 